УДК 342.95:656.7

DOI https://doi.org/10.32849/2663-5313/2020.2.59

Олена Банчук-Петросова,

канд. наук з держ. упр.,

доиент кафедри державного управління і права

Київського національного університету культури

\title{
ПРОБЛЕМИ РЕГУЛЮВАННЯ МІЖНАРОДНИХ АВІАЦЙНИХ ПЕРЕВЕЗЕНЬ ПАСАЖИРІВ ТА ШЛЯХИ УДОСКОНАЛЕННЯ ЗАКОНОДАВСТВА
}

У статті досліджено проблеми регулювання міжнародних авіачійних перевезень пасажирів та шляхи удосконалення законодавства. Зокрема, встановлено, що нині негайного розгляду і вирішення потребують проблеми недосконалості нормативно-правового регулювання механізму забезпечення безпеки польотів, а також невідповідності інформачійного забезпечення безпеки польотів сучасним умовам, що ускладнює своєчасне прийняття рішень для запобігання надзвичайним ситуачіям.

3 метою удосконалення захисту прав пасажирів та екіпажів повітряних суден вітчизняних авіаиійних компаній запропоновано внести відповідні зміни до Кримінального кодексу України. Зокрема, запропоновано доповнити норми иього кодексу ст. 416-1, виклавщи ї у такій редакиіи: «невиконання або неналежне виконання уповноваженими органами чи посадовими особами своїх професійних обов'язків у сфері забезпечення безпеки пасажирів та персоналу повітряного судна, що спричинило тяжкі наслідки, - карається позбавленням волі на строк від п'яти до п’ятнадияти років».

Наголошується на необхідності якнайшвидшого ухвалення проєкту Авіаційної транспортної стратегії на період до 2030 року, згідно з положеннями якої «шляхами розв'язання існуючих проблем у сфері безпеки авіачійного транспорту є реалізачія державної політики в сфері авіаційної безпеки з урахуванням Державної програми авіачійної безпеки чивільної авіачії, затвердженої Законом України від 21 березня 2017 р. № 1965-VIII, забезпечення налляду за станом ї̈ реалізачї̈ суб'єктами авіаиійної діяльності відповідно до додатка 17 до Конвениії про міжнародну иивільну авіацію, а також утворення єдиного иентру збору та аналізу подій в иивільній авіаиій для прийняття оптимального рішення у разі інииденту чи акту незаконного втручання». 3 огляду на зазначене, начіональне законодавство Украйни, що забезпечує нормативно-правове регулювання міжнародних авіачійних перевезень пасажирів наразі все ще потребує удосконалення.

Ключові слова: проблеми регулювання, міжнародні авіаційні перевезення пасажирів, безпека пасажирів, безпека авіаційного персоналу повітряних суден, національне законодавство.

Постановка проблеми. Світова система транспорту немислима без авіації. Нині спостерігається позитивна динаміка авіаційних перевезень, а роль авіації у світовому масштабі складно переоцінити.

Значний потенціал розвитку авіаційного ринку сьогодні має й наша держава Ринок пасажирських авіаперевезень має найшвидші 3-поміж всіх видів транспорту України темпи зростання. Такі перспективи зумовлені насамперед значним відкладеним попитом на авіаперевезення, а також сприятливим географічним розташуванням для розвитку транзитних перевезень.

Сьогодні, коли наша країна перебуває в умовах масштабного реформування, $€$ усі шанси для створення повноцінного конкурентоспроможного авіаційного ринку та розвитку в Україні європейського логістичного вузла.

Однак на шляху до даної мети натепер стоїть чимало перешкод, усунення яких потребує відповідних наукових напрацювань. Це зумовлює актуальність дослідження.

Одним із аспектів нормативно-правового регулювання міжнародних авіаційних перевезень пасажирів є безпека пасажирів, авіаційного персоналу та персоналу, який задіяний в авіаційній діяльності, повітряних суден.

Нині в законодавстві України наявні нормативно-правові акти, покликані забезпечувати безпеку використання повітряних суден в Україні, а також пасажирів, авіаційного персоналу та персоналу, який задіяний в авіаційній діяльності. Проте, попри нормативно-правове регулювання даного питання, існує чимало проблем щодо забезпечення безпеки використання повітряних суден, які потребують негайного розгляду і вирішення. Серед них - недосконалість нормативноправового регулювання механізму забезпечення безпеки польотів, а також невідповідність інформаційного забезпечення безпеки польотів сучасним умовам, що ускладнює 
своєчасне прийняття рішень для запобігання надзвичайним ситуаціям.

Аналіз останніх досліджень і публікацій. Питання правового регулювання міжнародних пасажирських авіаперевезень неодноразово привертало увагу науковців. Зокрема, окремі аспекти цієї теми вивчали: О. П. Радчук, Д. Ю. Маркуш, І. В. Островська, О. А. Радченко, Н. В. Моісеєва та ін.

Однак, попри внесок вітчизняних науковців у розробку цієї теми, маловивченими залишаються окремі проблеми правового регулювання міжнародних перевезень пасажирів авіаційним транспортом. Зокрема, поза увагою науковців залишається питання удосконалення вітчизняного законодавства, що забезпечує нормативно-правове регулювання міжнародних пасажирських авіаперевезень, які здійснюються вітчизняними авіакомпаніями. Це, своєю чергою, зумовлює потребу відповідних наукових напрацювань.

Мета статті - на основі аналізу результатів загальнотеоретичних та галузевих досліджень, нормативно-правової бази з теми дослідження визначити проблеми регулювання міжнародних авіаційних перевезень пасажирів та шляхи удосконалення законодавства.

Виклад основного матеріалу. Практика діяльності українських та іноземних авіаперевізників свідчить про те, що авіація є сучасним безпечним та затребуваним способом пасажирських перевезень. Загалом розвиток національного регулювання перевезень авіаційним транспортом відповідає міжнародному законодавству, а також сприяє збільшенню кількості таких перевезень [11, с. 150].

Так, зокрема, за січень-лютий 2018 року кількість пасажирських перевезень авіакомпаніями України зросла порівняно 3 відповідним періодом минулого року на $8,8 \%$ та становила 1 344,4 тис. осіб, у т. ч. міжнародні - на 8,3\%, що становили 1 197,4 тис. осіб.

2016 рік відзначився відновленням ринку пасажирських перевезень після спаду у 2014-2015 рр. У результаті цього обсяги пасажирських перевезень вітчизняних авіакомпаній перевищили показник «докризового» 2013 року на $2,1 \%$, а у 2017 році - вже на $30,1 \%$.

Протягом 2017 року пасажирські перевезення здійснювали 18 вітчизняних авіакомпаній. Згідно зі статистичних даними за 2017 рік, 93\% загальних обсягів пасажирських перевезень було здійснено п'ятьма провідними авіаперевізниками. Крім авіакомпанії «Міжнародні авіалінії України», лідерство зберігається за такими компаніями, як «Роза вітрів», «Азур Ейр Україна», «Атласджет Україна» та «Браво» [8]. При цьому авіакомпанією «Роза вітрів» було досягнуто зростання обсягів пасажирських перевезень порівняно з попереднім 2016 роком в 2,5 рази, авіакомпанями «Атласджет Україна» - на 73,8\%, «Браво» - на 49,9\%, «Азур Ейр Україна» - на 17,2\% та «Міжнародні авіалінії України» - на 16,5\% [8].

Найбільший темп приросту кількості перевезених пасажирів вітчизняними авіакомпаніями спостерігався в такому сегменті ринку авіаперевезень, як міжнародні польоти на нерегулярній основі: 49,2\% за звітний рік, 15 українських авіакомпаній перевезли 3 777,0 тис. пасажирів. При цьому 85\% таких перевезень було здійснено чотирма авіакомпаніями, такими як «Роза вітрів», «Міжнародні авіалінії України», «Азур Ейр Україна», «Браво» [6, с.24].

За прогнозами, до 2030 року пасажиропотік через аеропорти України зросте в 4,3 рази проти показника 2017 року - до 71,2 млн. із 16,5 млн. осіб [7].

Однак нещодавня трагічна подія - авіакатастрофа боїнгу $737^{1}$ - дає підстави стверджувати, що, на жаль, у сфері міжнародних повітряних пасажирських перевезень, що здійснюються українськими авіакомпаніями, не все так бездоганно.

На нашу думку, цієї трагедії можна було $б$ уникнути, якби не такі дві основні проблеми, як недосконалість нормативно-правового регулювання механізму забезпечення безпеки польотів, а також невідповідність інформаційного забезпечення безпеки польотів сучасним умовам, що ускладнюе своєчасне прийняття рішень для запобігання надзвичайним ситуаціям. Обгрунтування цих припущень таке.

Як відомо, джерелами правового регулювання міжнародних перевезень, порівняно з внутрішніми, $€$ не лише міжнародно-правові акти, а й національне законодавство [5, с. 389] окремих країн. Українське законодавство у цій сфері потребує перегляду з огляду на низьку ефективність законодавчих положень.

Так, 21 березня 2017 року була прийнята Державна програма авіаційної безпеки цивільної авіації (далі - Програма) [9], роз-

${ }^{1}$ Boeing 737 авіакомпанії «Міжнародні авіалінії України» розбився незабаром після вильоту 3 аеропорту Імама Хомейні в Тегерані 8 січня 2020 року. Літак регулярного рейсу PS 752 Тегеран-Київ мав прибути до Міжнародного аеропорту «Бориспіль». 11 січня Іран визнав, що випадково збив український літак ракетою. До того про причетність до авіакатастрофи іранських військових заявляли прем'єр-міністри Великобританії, Канади та Австралії, а також американські 3MI 3 посиланням на Пентагон. 
роблена відповідно до стандартів та рекомендованої практики Конвенції про міжнародну цивільну авіацію (Чикаго, 7 грудня 1944 року) та зобов'язань, що випливають з участі України у Конвенції про злочини та деякі інші акти, що вчинюються на борту повітряних суден (Токіо, 14 вересня 1963 року), Конвенції про боротьбу 3 незаконним захопленням повітряних суден (Гаага, 16 грудня 1970 року), Конвенції про боротьбу з незаконними актами, спрямованими проти безпеки цивільної авіації (Монреаль, 23 вересня 1971 року), з Протоколу про боротьбу з незаконними актами насильства в аеропортах, які обслуговують міжнародну цивільну авіацію (Монреаль, 24 лютого 1988 року), Конвенції про маркування пластичних вибухових речовин з метою їх виявлення (Монреаль, 1 березня 1991 року), Додатка 17 до Конвенції про міжнародну цивільну авіацію «Безпека. Захист міжнародної цивільної авіації від актів незаконного втручання», Керівництва $з$ авіаційної безпеки (Doc 8973), а також інших міжнародних актів та актів законодавства України. Тобто, Державна програма авіаційної безпеки цивільної авіації розроблена відповідно до міжнародних стандартів.

Однак вітчизняний механізм її реалізації $€$ недосконалим та недієвим. Зокрема, метою цієї Програми є розподіл обов'язків, встановлення правил впровадження та здійснення заходів забезпечення авіаційної безпеки пасажирів, авіаційного персоналу та персоналу, який задіяний в авіаційній діяльності, повітряних суден, майна, яке перевозиться повітряними суднами, об'єктів суб'єктів авіаційної діяльності незалежно від форми власності та підпорядкування.

Відповідно до положень Розділу 5 Програми [9], уповноваженим органом у сфері авіаційної безпеки цивільної авіації є центральний орган виконавчої влади, що реалізує державну політику в галузі цивільної авіації (далі - уповноважений орган з питань цивільної авіації). Звідси випливає, що саме до повноважень цього органу належить розроблення, впровадження та забезпечення виконання Державної програми авіаційної безпеки цивільної авіації, зокрема, й у частині забезпечення авіаційної безпеки цивільної авіації України.

Відповідний обов'язок щодо забезпечення авіаційної безпеки опосередковано на органи державної влади покладається й Розділом 10 Правил повітряних перевезень та обслуговування пасажирів і багажу, де зазначається, що «авіаперевізник має право відмовити в перевезенні на будь-якому етапі повітряного перевезення, анулювати бронювання або зняти пасажира з борту повітряного судна:

- у зв’язку з необхідністю виконання вимог законодавства країни місця відправлення, місця прибуття або транзиту;

- на вимогу уповноважених органів державної влади України» [10].

Проте, за словами президента компанії «Міжнародних авіаліній України», на момент вильоту літака із аеропорту «Бориспіль» жодної інформації про можливі загрози в авіакомпанії не було, як і під час виконання рейсу з аеропорту Тегерана [12]. Тоді як закордонні міжнародні авіакомпанії почали перенаправляти рейси з повітряного простору Ірану після того, як країна запустила кілька ракет по американській військовій базі «Аін Аль-Асад» на заході Іраку [1].

3 огляду на вказане, дещо дискусійною видається ситуація щодо повного перекладання відповідальності за катастрофу українського Boeing 737 на владу Ірану. Маємо на увазі схвалену Верховною Радою України заяву, якою «українські парламентарі поклали повну відповідальність за катастрофу українського Boeing 737 на владу Ірану» [3]. I хоча український парламент закликав Міжнародну організацію цивільної авіації (далі - ІКАО) вжити заходів щодо своєчасної оцінки ризиків польотів цивільної авіації задля запобігання подібним трагедіям у майбутньому, а також звернувся до міжнародних партнерів з пропозицією спільно розробити для цього дієві політичні й технічні механізми, що, безперечно, є вагомим кроком уперед на шляху до вирішення проблеми забезпечення авіаційної безпеки пасажирів, авіаційного персоналу та персоналу, який задіяний в авіаційній діяльності, повітряних суден, у діяльності уповноважених органів та осіб у сфері авіаційної безпеки вітчизняної цивільної авіації присутня недбалість, що призвела до численних людських жертв.

Однак це поки лише наші припущення. Слід зазначити, що факт повідомлення/не повідомлення такої інформації уповноваженим особам Міжнародних авіаліній України з боку органів державної влади України має бути предметом відповідних розслідувань. У разі ж встановлення факту такого роду службової недбалості винних осіб має бути притягнуто до кримінальної відповідальності. 3 цією метою доцільно було б внести відповідні зміни до Кримінального кодексу України. Зокрема, пропонуємо доповнити норми цього кодексу ст. 416-1, виклавши iii у такій редакції: «невиконання або неналежне виконання уповноваженими органами чи посадовими особами своїх професійних 
обов’язків у сфері забезпечення безпеки пасажирів та персоналу повітряного судна, що спричинило тяжкі наслідки, - карається позбавленням волі на строк від п'яти до п'ятнадцяти років». На нашу думку, запровадження кримінальної відповідальності у цій сфері буде дієвим стимулом та допоможе у майбутньому запобігти трагічним подіям, подібним до авіакатастрофи боїнгу 737.

Крім того, якнайшвидшого ухвалення потребує проєкт Авіаційної транспортної стратегії на період до 2030 року, згідно з положеннями якої «шляхами розв'язання існуючих проблем у сфері безпеки авіаційного транспорту є

- реалізація державної політики в сфері авіаційної безпеки з урахуванням Державної програми авіаційної безпеки цивільної авіації, затвердженої Законом України від 21 березня 2017 р. № 1965-VIII, забезпечення нагляду за станом її реалізації суб'єктами авіаційної діяльності відповідно до додатка 17 до Конвенції про міжнародну цивільну авіацію;

- утворення єдиного центру збору та аналізу подій в цивільній авіації для прийняття оптимального рішення у разі інциденту чи акту незаконного втручання» [2].

На нашу думку, такі заходи допоможуть значно покращити ситуацію стосовно забезпечення безпеки польотів, що сприятиме більш ефективному захисту прав пасажирів міжнародних авіаційних перевезень, здійснюваних вітчизняними авіакомпаніями, а також персоналу таких повітряних суден.

\section{Висновки}

Загалом, підсумовуючи вищесказане, можна зробити висновок, що національне законодавство України, що забезпечує нормативно-правове регулювання міжнародних авіаційних перевезень пасажирів наразі все ще потребує удосконалення. Зокрема, вирішення на законодавчому рівні потребують проблеми недосконалості нормативно-правового регулювання механізму забезпечення безпеки польотів, а також невідповідності інформаційного забезпечення безпеки польотів сучасним умовам, що ускладнюе своєчасне прийняття рішень для запобігання надзвичайним ситуаціям.

Необхідно насамперед утворити єдиний центр збору та аналізу подій в цивільній авіації, що дасть змогу приймати оптимальне рішення у разі інциденту чи акту незаконного втручання.

Крім того, доцільно встановити відповідальність за невиконання або неналежне виконання уповноваженими органами чи посадовими особами своїх професійних обов'язків у сфері забезпечення безпеки пасажирів та персоналу повітряного судна.

До того ж на часі ухвалення Авіаційної транспортної стратегії. Тим паче 3 огляду на те, що нині вже існує досить вдала редакція проєкту Авіаційної транспортної стратегії до 2030 року.

Насамкінець, слід зауважити, що проблеми регулювання міжнародних авіаційних перевезень пасажирів потребують подальшого наукового дослідження щодо пошуку шляхів удосконалення національного законодавства у цій сфері з метою покращення захисту прав пасажирів та авіаційного персоналу повітряного судна.

\section{Список використаних джерел:}

1. Авіакомпанії перенаправляють рейси 3 повітряного простору Iрану. URL https://espreso.tv/news/2020/01/08/ aviakompaniyi_perenapravlyayut_reysy_z povitryanogo_prostoru_iranu (дата звернення: 26.01.2020).

2. Авіаційна транспортна стратегія на період до 2030 року : проєкт. URL: www.mtu.gov.ua (дата звернення: 26.01.2020).

3. Верховна Рада схвалила заяву щодо відповідальності Ірану за збиття літака MAУ. URL: https://zaxid.net/verhovna_rada_poklala_povnu_ vidpovidalnist_za_katastrofu_ukrayinskogo_ boeing_737_na_iran_n1495997 (дата звернення: 26.01.2020).

4. Кримінальний кодекс України: Закон України від 05.04.2001 № 2341-III. URL: https: / / zakon.rada.gov.ua/laws/show/ 2341-14 (дата звернення: 26.01.2020).

5. Маркуш Д. Ю. Особливості сучасного міжнародно-правового регулювання повітряних перевезень вантажів. Порівняльно-аналітичне право. 2017. № 5. C. 389-391.

6. Островська I. В., Радченко О. А., Моiсеєва Н. В. Проблеми та напрями розвитку ринку авіаційних перевезень України. Економіка та управлінням національним господарством. 2018. № 4. C. 21-26.

7. Офіційний сайт Міністерства інфраструктури України. URL: http://www.mtu.gov.ua/ (дата звернення: 26.01.2020).

8. Підсумки діяльності авіаційної галузі України за 2017 рік. URL: URL: http://www.avia.gov.ua/ (дата звернення: 26.01.2020).

9. Про Державну програму авіаційної безпеки цивільної авіації : Закон України від 21.03.2017 № 1965-VIII. URL: https://zakon.rada.gov.ua/laws/ card/1965-19 (дата звернення: 26.01.2020).

10. Про затвердження Авіаційних правил України «Правила повітряних перевезень та обслуговування пасажирів і багажу»: наказ Державної авіаційної служби України від 26.11.2018 № 1239. URL: https://zakon.rada.gov.ua/laws/show/z0141-19 (дата звернення: 26.01.2020).

11. Радчук О. П. Міжнародно-правове регулювання авіаційних перевезень. Форум права. 2015. № 2. C. 144-151. 
12. У «МАУ» пояснили, чому не скасували польоти в Іран до катастрофи. URL https://zik.ua/news/2020/01/11/u_mau_ne bulo_informatsii_pro_mozhlyvi_zahrozy_na moment vylotu z aeroporta teheranu prezydent mau_95 $\overline{4} 14$ (дата звернення: 26.01.2020).

The article deals with the problems of regulation of international air transportation of passengers and ways of improving the legislation. In particular, it has been established that the problems of regulatory imperfection of the flight safety mechanism, as well as the inadequacy of the information security of the flight safety to the current conditions, which complicates timely decision making to prevent emergencies, currently require immediate consideration and resolution.

In order to improve the protection of the rights of passengers and crews of aircrafts of domestic airlines, it is proposed to amend the Criminal Code of Ukraine accordingly. In particular, it is proposed to supplement the provisions of Article 416-1 of this Code to have the following version: "Failure to perform or improper performance by the authorities or officials of their professional duties to ensure safety of passengers and aircraft personnel which have caused grave consequences shall be punishable by imprisonment for a term of five to fifteen years."

The need for the early adoption of the draft Aviation Transport Strategy for the period until 2030 is emphasized, according to the provisions of which "the ways of solving existing problems in the field of aviation safety are the implementation of the state aviation security policy, taking into account the State Aviation Security Program for Civil Aviation, approved by Law of Ukraine No. 1965-VIII dated March 21, 2017, ensuring oversight of its implementation by air entities in accordance with Annex 17 to the Convention on International Civil Aviation, as well as the creation of a single center for the collection and analysis of events in civil aviation to make the best decision in the event of an incident or act of unlaw ful interference." The national legislation of Ukraine that provides for the regulation of international air passenger transportation still needs to be improved. In particular, the problems of imperfection of the regulatory framework of the flight safety mechanism, as well as the inadequacy of the information security of the flight safety to modern conditions, which complicates timely decision-making to prevent emergencies, require solutions at the legislative level.

Key words: regulatory issues, international passenger air transportation, passenger safety, aircraft personnel safety, national legislation. 